\title{
Journal of Environmental Sciences
}

\section{JOESE 5}

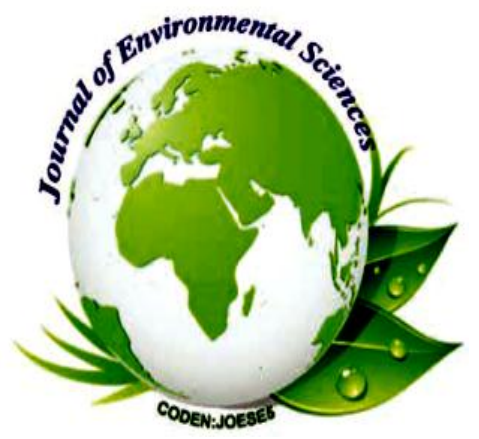

Petrophysical evaluation of the Messinian Abu Madi Formation in Salma delta gas field, northeastern onshore Nile Delta, Egypt

\author{
Mohamed El-Sharawy $^{a^{*}}$, Mahmoud Leila ${ }^{a}$, Ali Bakr ${ }^{\mathrm{b}}$, Adel Kamel ${ }^{\mathrm{a}}$ \\ ${ }^{a}$ Geology Department, Faculty of Science, Mansoura University, Egypt \\ ${ }^{\mathrm{b}}$ Rockserv petroleum company, Cairo, Egypt
}

\section{Reprint}

Volume 49, Number 2: 46 - 53

(2020) 


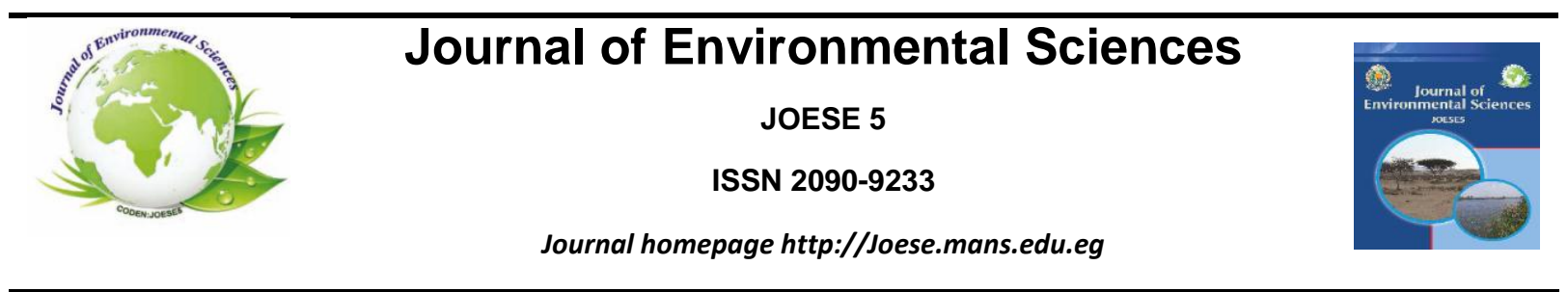

Original Article

\title{
Petrophysical evaluation of the Messinian Abu Madi Formation in Salma delta gas field, northeastern onshore Nile Delta, Egypt
}

\author{
Mohamed El-Sharawy $^{\mathrm{a}^{*}}$, Mahmoud Leila ${ }^{\mathrm{a}}$, Ali Bakr ${ }^{\mathrm{b}}$, Adel Kamel $^{\mathrm{a}}$ \\ ${ }^{a}$ Geology Department, Faculty of Science, Mansoura University, Egypt \\ ${ }^{\mathrm{b}}$ Rockserv petroleum company, Cairo, Egypt
}

\begin{tabular}{|c|c|}
\hline Article Info & Abstract \\
\hline Article history: & The clastic sediments of the Abu Madi Formation host the main gas- \\
\hline Received 22/ $11 / 2019$ & $\begin{array}{l}\text { bearing reservoirs in the Nile Delta, Egypt. The current study integrates seismic and } \\
\text { well logging analysis in order to shed light on the Abu Madi formation in Salma }\end{array}$ \\
\hline Received in revised & delta gas field which locates outside the Abu Madi main canyon. In the study area, \\
\hline form $17 / 12 / 2019$ & $\begin{array}{l}\text { Abu Madi Formation consists of sandstones, siltstones and shales which infill the } \\
\text { subaerial channels of the low-stand canyons incised during the Messinian salinity }\end{array}$ \\
\hline Accepted 21/12/2019 & $\begin{array}{l}\text { crisis (MSC). The pay zone sandstones are thicker on the channel margins and on } \\
\text { the upthrown parts of the faults, whereas the sandstones in the downthrown regions }\end{array}$ \\
\hline $\begin{array}{l}\text { Keywords: Nile Delta; } \\
\text { Messinian; Abu Madi } \\
\text { Formation; Reservoir; Well } \\
\text { logs; Petrophysics }\end{array}$ & $\begin{array}{l}\text { are often saturated with water despite their high porosity and low contents of clays. } \\
\text { Therefore, Salma delta- } 1 \text { and Salma delta- } 2 \text { wells drilled on the channel margins are } \\
\text { the best productive wells. The pay zone sandstones are characterized by dominantly } \\
\text { quartzose composition with low clay }(<30 \%) \text { and carbonate cement contents. The } \\
\text { clays are often present in laminated forms, and therefore have minimal impact on } \\
\text { porosity. The current study reveals that the best productive intervals of Abu Madi } \\
\text { sandstones are preferentially accumulated on the channel margins and on the up } \\
\text { thrown side of the main faults. }\end{array}$ \\
\hline
\end{tabular}

\section{Introduction}

After the recent gas discoveries onshore (e.g. Noras) and offshore (e.g. Zohr), the Nile Delta have become one of the biggest gas-producing provinces in Africa (e.g. Shehata, 2008; Leila and Moscariello, 2019; Leila et al., 2020). In 1967, the first successful gas discovery was encountered in Abu Madi gas Field which produces commercial gas from the Messinian Abu Madi Formation (EGPC,1994). Consequently, the Messinian Abu Madi sandstones have become the main target for gas exploration in the Nile Delta. These sandstones represent the incised valley-fill (IVF) deposits accumulated during the final stage of the Messinian salinity crisis (MSC).

The MSC is one of the most spectacular mass movement events that shaped the landscape of the entire Mediterranean region. It occurred due to the temporary closure of the Strait of Gibraltar between $\sim 5.97$ - 5.33 Ma resulting in a restricted water flux between the Atlantic Ocean and Mediterranean Sea which led to a partial desiccation of the Mediterranean with a dramatic sea-level drawdown of more than $1000 \mathrm{~m}$ (Hsü et al., 1973; Sternai et al., 2017). In the Nile Delta, the MSC event was accompanied by the incision of the Eonile canyon which incised through the pre-MSC sediments and was later infilled by the Abu Madi sandstones during sea level low-stand and subsequent backstepping infill during late MSC (e.g. Salem et al., 2005; Leila and Moscariello, 2019). The Abu Madi reservoirs outside the main canyon system are poorly investigated, and very little information is known about their petrophysical properties and percentage of main net pay. Therefore, the main objective of this study is to delineate the petrophysical characteristics of the Abu Madi Formation in Salma Delta Field which lies outside the main canyon in northeastern onshore part of the Nile delta (south-west Manzala lake) (Fig. 1).

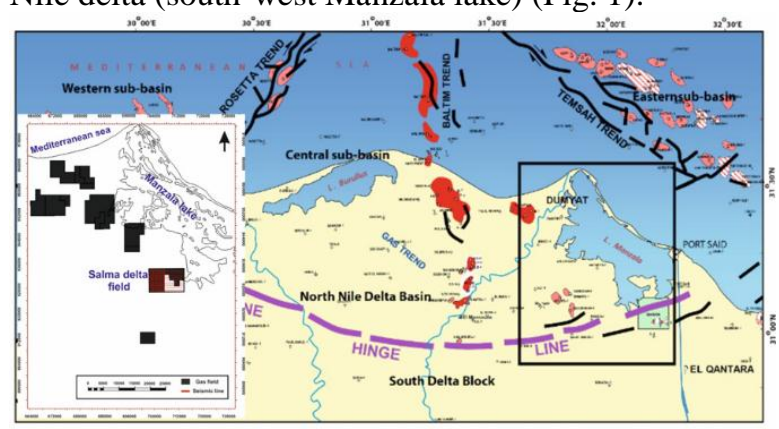


Figure 1. Location map of the study area in the eastern onshore part of the Nile Delta to the east of the Abu Madi main canyon.

\section{Geologic setting}

The Nile delta is a passive margin basin in the southeastern part of the eastern Mediterranean; it was initially developed during Late Eocene in an area close to the Qattara depression in the Western Desert (Said, 1990; Sestini, 1995). In Late Miocene, the Nile Delta was moved to its current position after the major drawdown in the Mediterranean Sea level during the Messinian salinity crisis (MSC) (Issawi and McCauley, 1992). The Nile delta basin represents part of the unstable shelf of the partially deformed northern margin of the African plate (Said, 1990; Sarhan and Hemdan, 1994). Several major structural features control its stratigraphic evolution. Among these are the E-W Hinge zone, the NW Rosetta fault trend, the NE Temsah structural trend, the Pelusim shear zone, and the NW Red Sea-Gulf of Suez fault trend as well as some minor trends such as the N-S Baltim fault trend (May, 1991; Dolson et al., 2005). The study area (Salma Delta Field) lies in the northeastern part of the central sub-basin where the Neogene sediments are thickening and host the most prospective reservoir intervals (Fig. 2; EGPC, 1994). The Miocene succession has the greatest thickness in the study area (Fig. 2), and it hosts the most potential reservoirs. It begins with a major flooding which prevailed during Burdigalian and northern Egypt was covered by shales of the Qantara Formation (Rizzini et al., 1978; EGPC, 1994; Dolson et al. 2005). Langhian - Serravallian witnesses an irregular phase of transgression and regression which led to deposition of marine shales interbedded with shallow marine sandstones (Sidi Salem Formation).

Deltaic sedimentation prevailed during Tortonian and resulted in accumulation of the thick conglomerates and sandstones (Qawasim Formation) (Rizzini et al., 1978; Said, 1990; Dolson et al., 2005; Leila and Moscariello; 2019), the environment of this formation changed from fluvial to shallow marine basinward (Barakat, 2010). During Late Messinian, the regression phase reached its maxima subsequent to the partial isolation of the Mediterranean from the Atlantic Ocean which led to subaerial incision in the margins and thick evaporites deposition within the basins (Hsü et al., 1973; Barber, 1981; Krijgsman et al., 1999). In the Nile Delta, the Eonile canyon was incised through the Qawasim and pre-Qawasim sediments (Dolson et al., 2005; Leila and Moscariello, 2019). During the late stage of the MSC, the Eonile canyon was infilled by the sediments of Abu Madi Formation. The distribution of the Abu Madi facies was controlled by paleotopography initiated by faulting, low-stand erosion and rapid deposition during the late Messinian (El Heiny et al., 1990; Leila and Moscariello, 2019). Abu Madi Formation is the main reservoir in Salama Delta gas field, its thickness varies among the wells (Figs. 7:10). It constitutes low-stand fluvial facies that were deposited during the initial sea level rise during the Late Messinian (Dolson et al., 2005; Rubino et al., 2015; Leila and Moscariello, 2019; Leila et al., 2020).

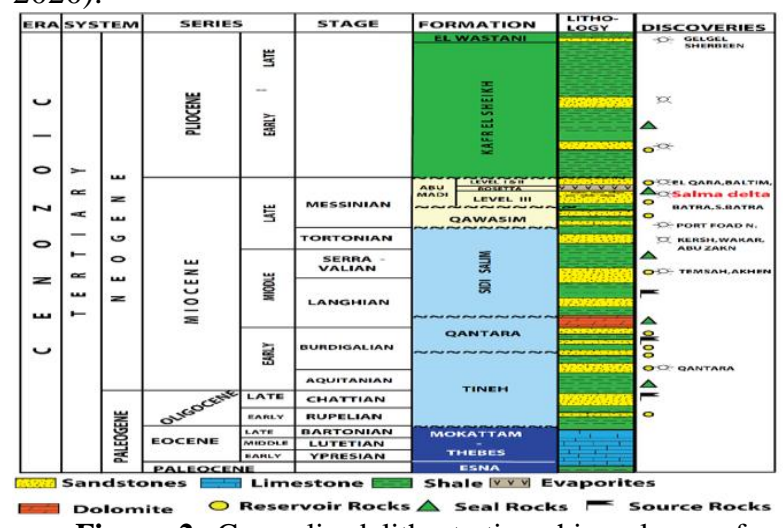

Figure 2. Generalized lithostratigraphic column of the study area (modified after Corex, 2007).

\section{Data and methods}

This study utilizes a comprehensive subsurface dataset including 20 2D seismic profiles passing through the study area which covering a surface area of $84 \mathrm{~km}^{2}$, and four wells from Salma delta Field (Salma delta-1, -2, -4, -5) (Fig. 3). The seismic and well data were studied and interpreted using Schlumberger petrel and Techlog software. The well data includes wireline logs and check shots that were utilized to tie the different stratigraphic intervals with seismic data. The logs were displayed to identify the lithologic characteristics of Abu Madi Formation and detect the hydrocarbon-bearing zones. The wireline logs were interpreted in order to deduce the different petrophysical parameters such as permeability, porosity, clay volume and water saturation. The clay volume was calculated using gamma ray $\log$ (Steiber, 1973). Porosity was calculated using a combination of density, neutron and sonic logs and clay volume was considered prior to the calculation of the effective porosity. Moreover, water saturation was computed using modified Simandoux equation (Simandoux, 1963). Several cross-plots were also applied to decipher the mode of clay distribution in the pore spaces as well as the lithologic and pore-system characteristics of the Abu Madi sandstones. 


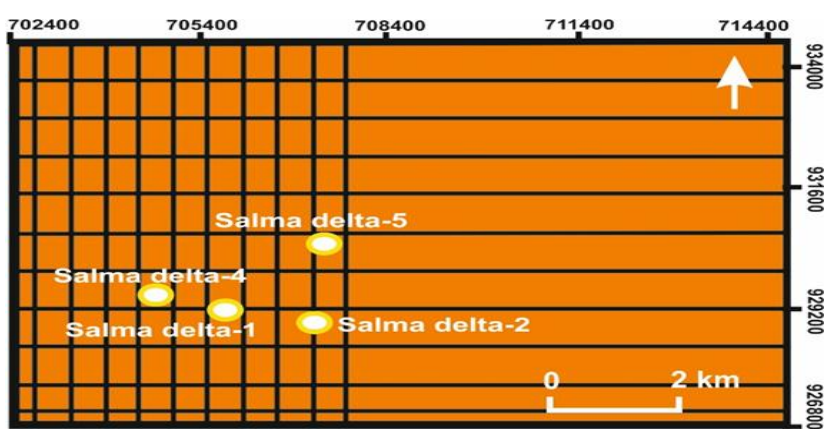

Figure 3. Location map of the 2D seismic survey used in this study

\section{Seismic interpretation}

The seismic profiles define the Messinian erosion surfaces corresponding to the Messinian event in the Nile Delta (Figs. 4, 5). The Messinian erosion surface (MES) marks the base of the MSC Abu Madi facies. The MES is defined by highamplitude, irregular and highly undulated seismic unconformity erosionally truncating the underlying pre-MSC facies. This surface documents the onset of erosion phase prevailed during the MSC in the Nile Delta (e.g. Barber, 1981; Dalla et al., 1997; Pigott and Abdel-Fattah, 2014; Leila and Moscariello, 2019). The depth (TWT) contour map of the MES illustrates the E-W and NW-SE trends of the Abo Madi incised valley (Fig. 6A).
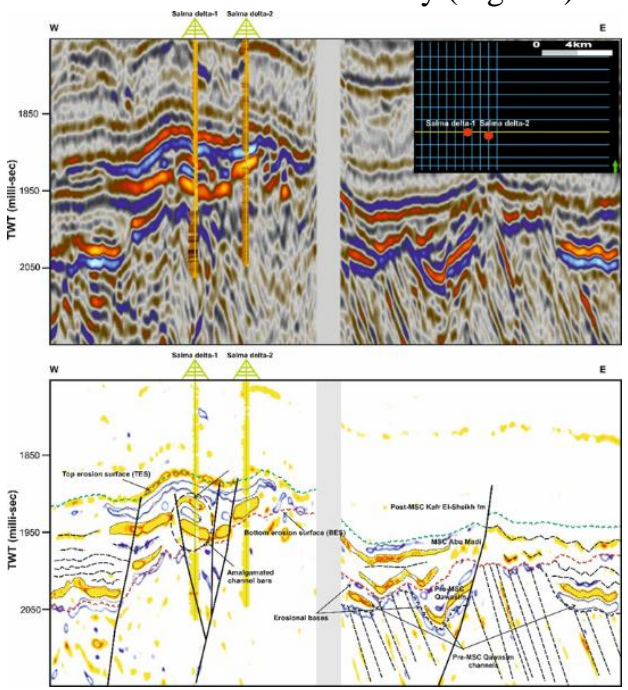

Figure 4. E-W seismic profile passing through Salma delta-1 and -2 wells illustrating the Abu Madi incised valley area and its infill facies in the study area.
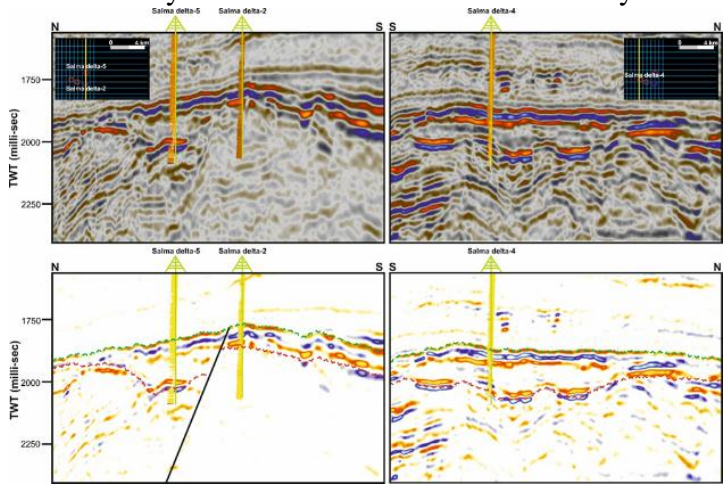

Figure 5. N-S seismic profiles passing through Salma delta-5, -2 and -4 wells illustrating the Abu Madi incised valley area and its infill facies in the study area.

The MSC seismic facies constitute lowcontinuity, parallel, vertically and laterally variable amplitude and frequency reflections occasionally onlapping the $\mathrm{V}$-shaped depressions of the MES (Figs. 4, 5). Their seismic amplitude increases vertically where the seismic facies change from partly chaotic and transparent at the base to flat, high-amplitude reflections upward. The MSC succession is dissected by normal faults forming several structural highs and lows which trap the MSC sediments. Near the deep-seated faults, the MSC facies become highly-irregular, transparent and locally display cone-in-cone morphology. The MSC reflections are capped by a prominent seismic unconformity surface likely corresponding to the top erosion surface (TES; e.g. Lofi et al., 2011a).
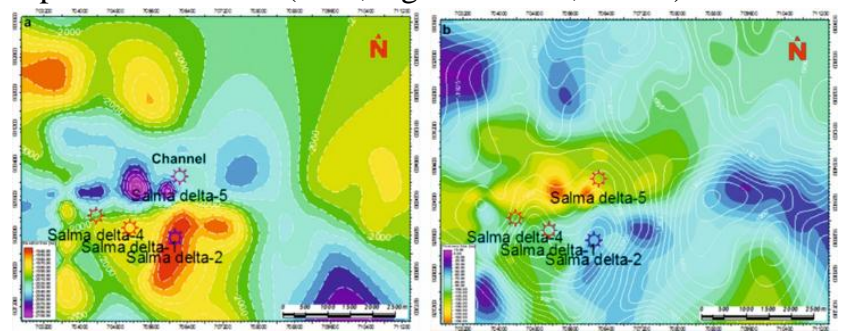

Figure 6. A) tow-way time (TWT) contour map of the BES illustrating the architecture of the Abu Madi incised valley in the study area, B) isopach map of the MSC Abu Madi facies reveals that their thickness often follows the main incisional troughs within the incised valley.

Herein, the TES is represented by an irregular, undulated, high-amplitude seismic reflector separating the underlying MSC facies from the overlying continuous and well-bedded post-MSC reflections (Figs. 4, 5). The TES is erosionallytruncating the MSC facies and concordant with the post-MSC reflections. The TES represents the end of the MSC in the entire Mediterranean realm; and likely related to the major marine flooding of the Mediterranean during the Early Pliocene (e.g. Garcia-Castellanos et al., 2009; Lofi et al., 2011a; Micallef et al., 2018). The thickness of the Abu Madi facies changes from the thicker facies in the center of the channel (Salma delta-5) to the thinner facies at the margins of the canyon (Salma delta-1, 2) (Fig. 6B).

\section{Petrophysical properties of Abu Madi} Formation:

Determining the type and quantity of fluid saturations are the main objectives of the petrophysical formation evaluation which aids delineating the productivity of the reservoir intervals. The Abu Madi Formation typically consist 
of alternated sandstones, siltstones and shales (Figs. 9-12) (Rizzini et al., 1976; Leila et al., 2018).

Table 1. Petrophysical parameters of the Abu Madi Formation in the studied wells of Salma delta gas field.

\begin{tabular}{l|c|c|c|c}
\hline Parameters & Salma delta-1 & Salma delta-2 & Salma delta-4 & Salma delta-5 \\
\hline Gross thickness $(\boldsymbol{m})$ & 87.0 & 72.5 & 120.5 & 140 \\
\hline Net thickness $(\boldsymbol{m})$ & 27.5 & 24.8 & 12.0 & 0.915 \\
\hline Net / gross & 0.31 & 0.34 & 0.1 & 0.007 \\
\hline Porosity (\%) & 11.47 & 11.6 & 9.8 & 11.3 \\
\hline Clay volume (\%) & 53.54 & 58.4 & 53.1 & 35.0 \\
\hline Water saturation (\%) & 71.34 & 55.0 & 92.3 & 99.0
\end{tabular}

The gross thickness of Abu Madi clastics vary widely in the studied wells (Table 1), and the thickest succession $\sim 140 \mathrm{~m}$ occurs in Salma delta-5 well which is drilled in the center of the main channel (Fig. 5). Abu Madi Formation pinches out toward Salma delta-2 which is drilled on the periphery of the channel and on the upthrown part of the fault (Table 1, Figs. 4-5). However, the greatest net pay thickness occur in Salam delta-1 and Salma delta-2, whereas the lowest net pay thickness is recorded in Salma delta 5 (Table 1). Therefore, the highest net/gross (N/G) ratio occurs in Salma delta-2 and Salma delta-1 wells (0.34 and 0.31 , respectively). The highest average porosity value of $11.6 \%$ characterizes the Abu Madi sediments of Salma delta-2 well despite their elevated clay volume content $(\sim 58 \%)$. On the other hand, the Abu Madi succession of Salma delta-5 well hosts the minimum contents of clays with an average value of $35 \%$. This indicates that clays have a minimal impact on porosity because they are preferentially distributed in clay lamina which mostly impact the permeability rather than porosity (Fig. 11).

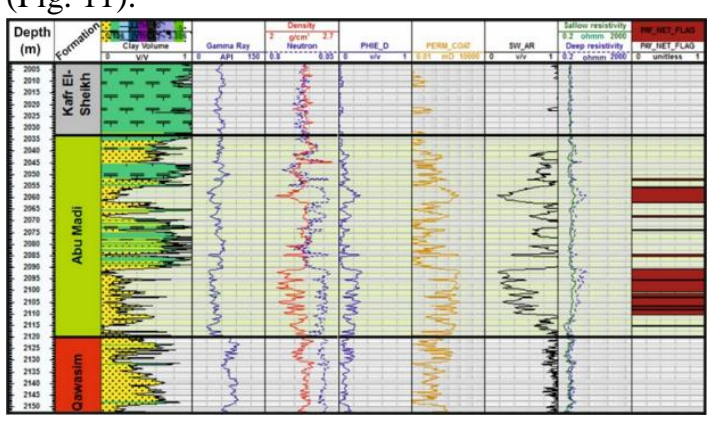

Figure 7. Litho-saturation cross-plot of the Abu Madi Formation in Salma delta-1 well.

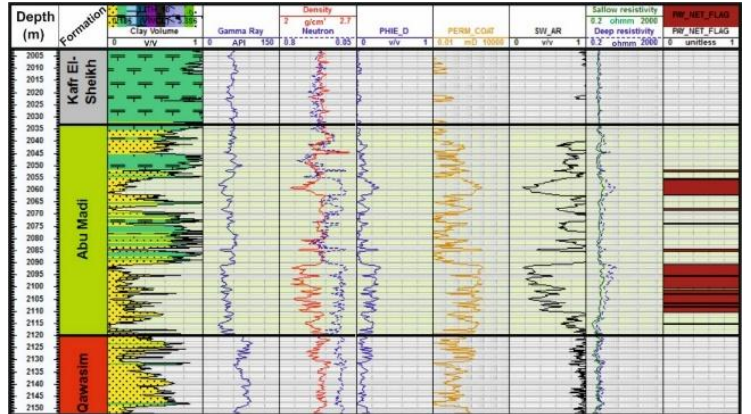

Figure 8. Litho-saturation cross-plot of the Abu Madi Formation in Salma delta-2 well.

The estimated water saturation of the Abu Madi sediments reveals elevated values generally greater than $50 \%$ with the lowest average value of $55 \%$ in Salma delta-2 well, whereas the highest average value of $99 \%$ occur in Salma delta-5 (Table 1). This explains the absence of gas-bearing intervals and the very low N/G ratio in Salma delta-5 well. Therefore, gas-bearing sandstones are only present in Salma delta-1, Salma delta-2 and Salma delta-4 wells where the gas effect is clearly defined as shown in the porosity crossplots (Fig. 11).

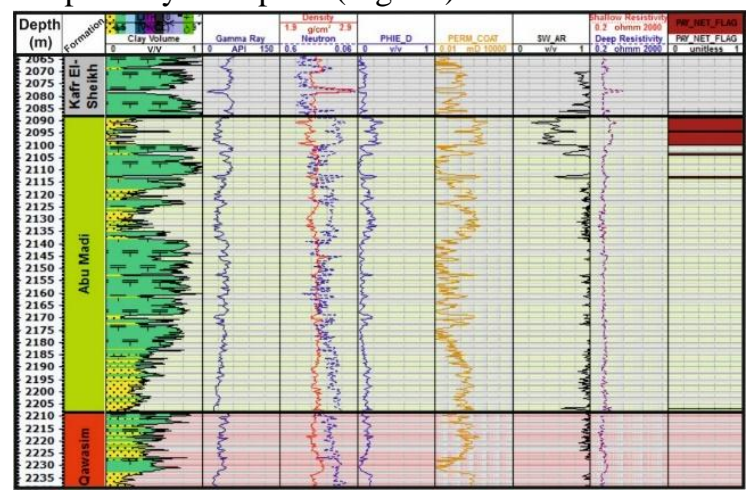

Figure 9. Litho-saturation cross-plot of the Abu Madi Formation in Salma delta-4 well.

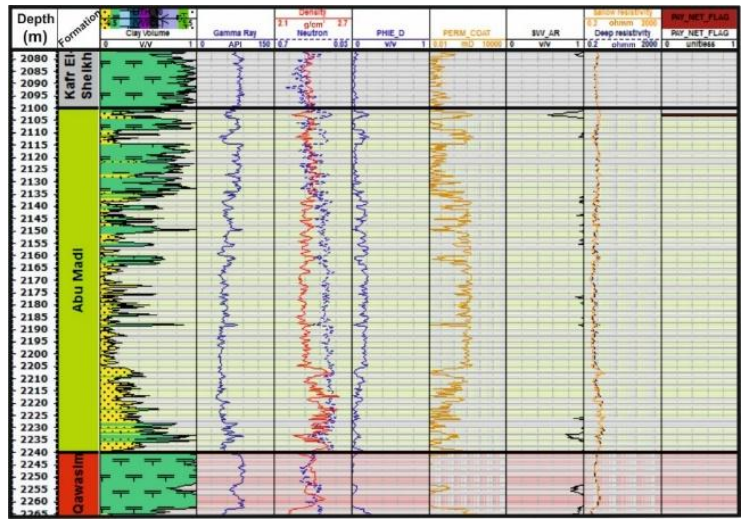

Figure 10. Litho-saturation cross-plot of the Abu Madi Formation in Salma delta-5 well.

Moreover, the absence of gas effect in the Abu Madi sediments of Salma delta-5 confirms the absence of pay zone intervals. Accordingly, from the comparison between wells, Salma-5 is a dry well, this may back to the migration of hydrocarbon because this well is the deepest well in the study 
area. In Salma-1, Salma-2 and Salma-4 pay zones are separated by shale bed, this reflects period of weak of the Eonile

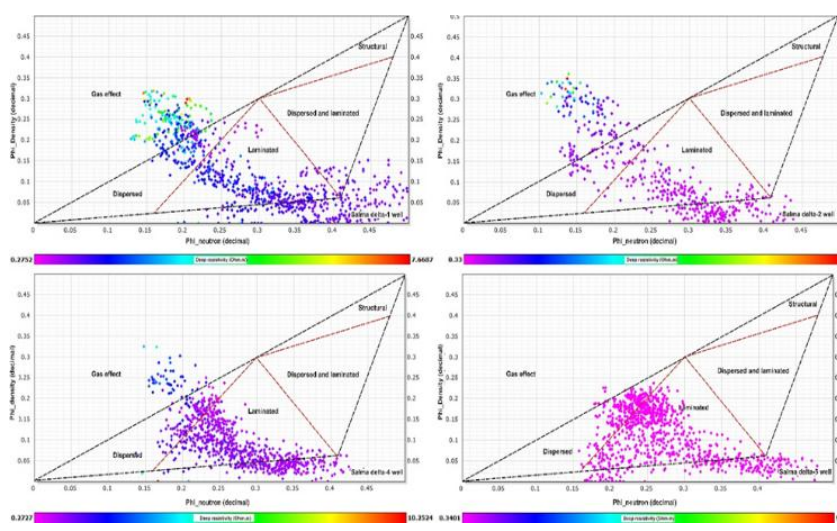

Figure 11. Neutron porosity versus density porosity cross-plots showing the mode of shale distribution within Abu Madi Formation in the studied wells.

Among well log interpretation is the identification of the lithologic controls on the hydrocarbon potentiality of the reservoir rocks (e.g. Schlumberger, 1997). Abu Madi IVF sediments are characterized by abundant shales, sandstones and siltstones with dominance of laminated clays in the shaley beds and dispersed and laminated clays in the sandy intervals (Fig. 11). The shale volume versus apparent matrix density cross-plots after taking into consideration the deep resistivity values reflect not only the matrix and rock composition but also the type of the pore-fluids (Fig. 12). The cross-plots reveal that the gas-saturated pay zone sandstones have a dominantly clean quartzose composition with minimal clay contents ranging from $5 \%$ and $3 \%$. The pay zone sandstones are abundant in Salma delta-1 and Salma delta-2 wells; whereas Salma delta-4 contain thin intervals of pay zone sandstones. Despite their clean quartzose composition with minimal volume of clay, the Abu Madi sandstones of Salma delta-5 are largely saturated with water. Moreover, the presence of carbonate cement in the pore spaces influences the hydrocarbon potentiality of the Abu Madi sandstones.

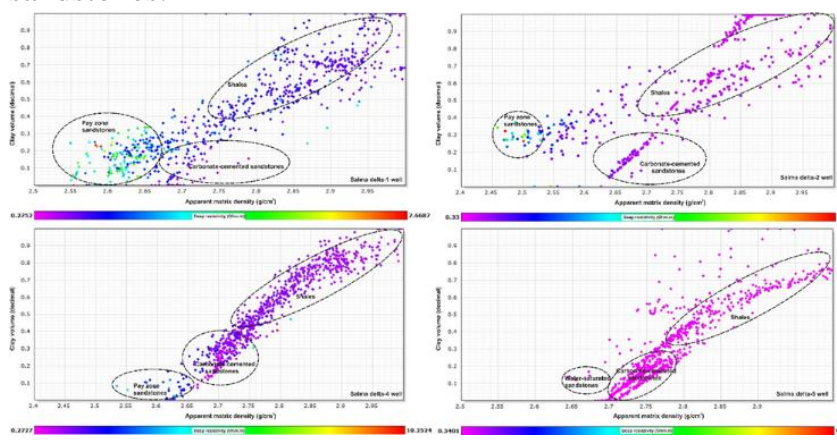

Figure 12. Cross-plots of shale volume versus apparent matrix density illustrating the litho-saturation characteristics of Abu Madi Formation in the studied wells.

The RHOB-NPHI cross-plots confirm that the gas-bearing zones consist mainly of clean sandstones with porosity values ranging from $20 \%$ and $30 \%$ (Fig. 13). Moreover, the carbonates and sandstones with abundant carbonate cement are often characterized by low deep resistivity values suggesting the absence of hydrocarbons. The crossplots also confirm the absence of gas-bearing sandstones in Salma delta-5 well despite the abundance of clean sandstones with high porosity values ranging from $25 \%$ and $30 \%$.
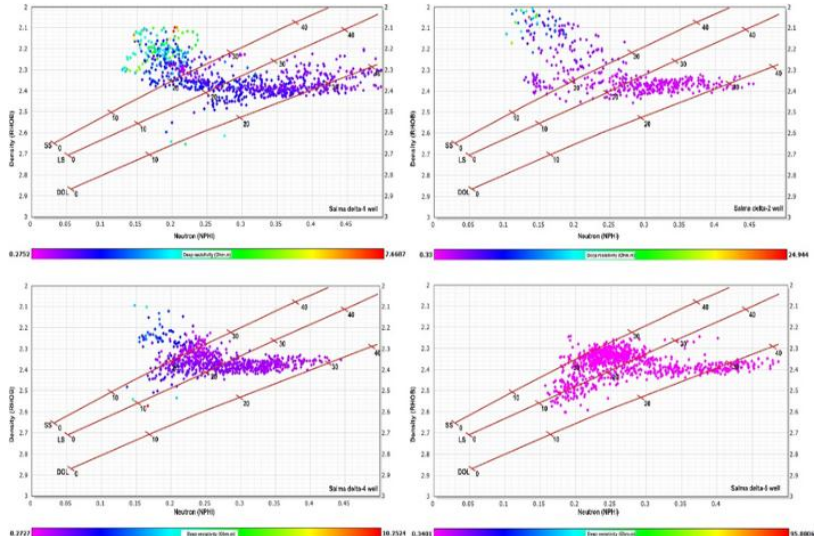

Figure 13. Neutron- Density cross-plots showing lithological characteristics of the Abu Madi Formation in the Salma delta field wells.

\section{Discussion and Conclusion}

This study aims to shed light on the petrophysical properties of the Abu Madi clastics in Salma delta gas field outside the Abu Madi main canyon. In the study area, Abu Madi sediments represent the incised-valley fills (IVF) of the lowstand canyons formed during the Messinian salinity crisis (MSC). The two-way time counter map reveals several EW and NW-SE trending channels that commonly infilled the Abu Madi sandstones and shales. The isopach map illustrates that the thicker sediments of the Abu Madi Formation occur in the center of the channel (Salma delta-5) and the thickness decreases toward the margins. Well log interpretation in terms of litho-saturation cross-plots reveal that the Abu Madi Formation consists mainly of sandstones interbedded with shales and siltstones. Thick pay zone sandstones and high N/G ratio ( 0.3) occur only in Salma delta-1 and Salma delta2 wells, whereas Salma delta- 5 well is dominated by water-saturated sandstones. The pay zone sandstones have dominantly quartzose composition with minimal contents of clays, carbonate cements and porosity values ranging from $20 \%$ and $30 \%$. The absence of pay zones in Salma delta-5, which is drilled in the center of the channel suggests that the 
hydrocarbon migration is active through faults which act as conduits from the deep targets into the upthrown sand bodies preferentially accumulated in the channel margins.

\section{Acknowledgments}

The authors would like to express their deepest gratitude and sincere appreciation to the Egyptian General Petroleum Corporation (EGPC) and El-Wastani Petroleum Company for providing the data needed for this research. We are also grateful for Schlumberger Company for granting the software used in this study.

\section{References:}

Barakat, M.Kh. (2010). Modern Geophysical Techniques for Constructing a 3D Geological Model on the Nile Delta, Egypt, Dissertation. Technical University of Berlin.

Barber, P.M. (1981). Messinian subaerial erosion of the Proto-Nile Delta. Mar. Geol., 44 : 253272.

Corex, (2007). Sedimentological and petrographic analyses on the cored Abu Madi Formation from Mansoura Concession, onshore Nile Delta, Egypt. (Unpublished Internal Reports).

Dalla, S.; Hamed, H. and Serrazi, M. (1997). Hydrocarbon exploration in a complex incised valley fill, An example from the late Messinian Abu Madi Formation (Nile Delta Basin, Egypt). Leading Edge., 18191824.

Dolson, J.C.; Boucher, P.J.; Siok, J. and Heppard, P.D. (2005). Key challenges torealizing full potential in an emerging giant gas province. Nile Delta/Mediterranean offshore, deep water, Egypt. Petrol Geol Conf series 6, pp., 607-624.

EGPC (Egyptian General Petroleum Corporation), (1994). Nile Delta and North Sinai fields, discoveries and hydrocarbon potentials (A comprehensive overview). EGPC, Cairo, Egypt., 387 pp.

El Heiny, I. and Rizk, Hassan, (1990). Sedimentological model for Abu Madi reservoir sands, Abu Madi field, Nile Delta, Egypt. 10th petroleum exploration and production Con. EGPC, Cairo., 2: 515-551.

Garcia-Castellanos, D.; Estrada, F.; Jiménez-Munt, I.; Gorini, C.; Fernàndez, M.; Vergés, J. and De Vicente, R. (2009). Catastrophic flood of the Mediterranean after the Messinian salinity crisis. Nature., 462: 778-781.

Hsü, K.J.; Cita, M.B. and Ryan, W.B.F., (1973). The origin of the Mediterranean evaporites, in A. Kaneps Ed, Leg 13, Initial Reports of the Deep Sea Drilling Project, 13 (2): 1203-1231.

Issawi, B. and McCauley, J.F. (1992). The Cenozoic rivers of Egypt: the Nile problem. In: Adams, B., Friedman, R., (eds.), The Followers of Horus: studies dedicated to Michael Allen Hoffman 1944-1990: Egyptian Studies Association Publication, v. 2, Oxbow Press, Oxford, United Kingdom, p. 121-138.

Krijgsman, W.; Hilgen, F.J.; Raffi, I.; Sierro, F.J. and Wilson, D.S. (1999). Chronology, causes and progression of the Messinian salinity crisis. Nature., 400: 652-655.

Leila, M,; Moscariello, A.; Kora, M.; Mohamed, A. and Samankassou, E. (2020). Sedimentology and reservoir quality of a Messinian mixed siliciclastic carbonate succession, onshore Nile Delta, Egypt. Mar. Petrol. Geol., 112: 104076.

Leila, M. and Moscariello, A. (2019). Seismic stratigraphy and sedimentary facies analysis of the pre- and syn-Messinain salinity crisis sequences, onshore Nile Delta, Egypt, Implications for reservoir quality prediction. Mar. Petrol. Geol., 101: 303-321.

Leila, M.; Moscariello, A. and Šegvić, B. (2018). Geochemical constraints on the provenance and depositional environment of the Messinian sediments, onshore Nile Delta, Egypt, Implications for the late Miocene paleogeography of the Mediterranean. J. Afr. Ear. Sci., 143: 215-241.

Lofi, J.; Sage, F.; Deverchere, J.; Loncke, L.; Maillard, A.; Gaullier, V.; Thinon, I.; Gillet, H.; Guennoc, P. and Gorini, C. (2011a). Refining our knowledge of the Messinian salinity crisis records in the offshore domain through multi-site seismic analysis. La Soc. Geol. Fr., 182 : 163-180.

May, P.R. (1991). The Eastern Mediterranean Mesozoic basin: evolution and oil habitat. AAPG Bull., 75: 1215-1232.

Micallef, A.; Camerlenghi A.; Garcia-Castellanos, D.; Otero, D.C.; Gutscher, M. A.; Barreca, G.; Spatola, D.; Facchin, L.; Geletti, R.; Sebastian, K.; Gross, F.; Urlaub, M. and (2018). Evidence of the Zanclean megaflood in the eastern Mediterranean Basin. Sci. Rep., 8: 1078.

Pigott, J. D. and Abdel-Fattah, M. (2014). Seismic stratigraphy of the Messinian Nile Delta coastal plain, Recognition of the fluvial Regressive Systems Tract and its potential for hydrocarbon exploration. J. Afr. Ear. Sci., 25: 9-21.

Rizzini, A.; Vezzani, F.; Coccocetta, V. and Milad, G. (1978). Stratigraphy and Sedimentation of Neogene-Quaternary section in the Nile 
Delta area, (A.R.E). Mar. Geol., 27: $327-$ 348.

Rubino, J.; Crouzy, E.; Campo, R.; Jardine, C.; Khalil, M.; Rives, T. and Rossi, T. (2015). Architecture and Stratigraphy of Messinian Deposits (Abu Madi Fm.) at the Mouth of Messinian Nile Canyon, Offshore Egypt. 77th EAGE Conf. \& Exhibition, Madrid., pp. 5.

Said, R. (1990). The Geology of Egypt. A. Balkema Publishers, USA.

Salem, A.M.; Ketzer, J. M.; Morad, S.; Rizk, R.R. and Al-Aasm, I. S. (2005). Diagenesis and reservoir-quality evolution of incised valley sandstones, evidence from the Abu Madi gas reservoirs (Upper Miocene), the Nile Delta Basin, Egypt. J. Sed. Res., 75: 572-584.

Sarhan, M. and Hemdan, K. (1994). North Nile delta structural setting trapping and mechanism. Egypt. Proc. 12th EGPC Expl. Prod. Conf, Cairo, Egypt., 1: 1-18

Schlumberger, (1997). Log Interpretation Charts, Schlumberger Wireline and Testing, Houston, Texas.

Sestini, G. (1995). Egypt, in H. Kulke Ed, Regional Petroleum Geology of The World, Part II, Africa, America, Australia and Antarctica (Beiträge zur regionalen Geologie der Erde 22, 66-87, Gebrüder Borntraeger Verlagsbuchhandlung, Stuttgart.

Shehata, A. (2008). Geological and petrophysical studies on Miocene oil reservoir of the deep target Sidi Salem sandstone, onshore Nile Delta, Egypt, MOC, Alex. Egypt, abstract.

Simandoux, P. (1963). Dielectric measurements on porous media: application to the measurement of the water saturations: Study of the behavior of argillaceous formations, Revue De I, institute francais Du Petrol 18, Supplementary Issue, 193215 , translated text in shaly sand reprint volume, SPWLA, Houston, pp: 97-124.

Steiber, R.G. (1973). Optimization of shale volumes in open hole logs. J. Petrol. Technol., 31: 147-162.

Sternai, P.; Caricchi, L.; Garcia-Castellanos, D.; Jolivet, L.; Sheldrake, T. and Castelltort, S. (2017). Magmatic pulse driven by sea-level changes associated with the Messinian salinity crisis. Nat. Geosci., 10: 783-787. 